\begin{tabular}{|l|l|l||}
\hline \multicolumn{2}{|c|}{ PublisherInfo } \\
\hline \hline PublisherName & $:$ & BioMed Central \\
\hline \hline PublisherLocation & $:$ & London \\
\hline \hline PublisherImprintName & $:$ & BioMed Central \\
\hline \hline
\end{tabular}

\title{
Mouse chromosomal deletions
}

\begin{tabular}{|l|l|l||}
\hline \multicolumn{2}{|c|}{ ArticleInfo } \\
\hline \hline ArticleID & $:$ & 3561 \\
\hline \hline ArticleDOI & $:$ & $10.1186 /$ gb-2000-1-1-reports027 \\
\hline \hline ArticleCitationID & $:$ & reports027 \\
\hline \hline ArticleSequenceNumber & $:$ & 52 \\
\hline \hline ArticleCategory & $:$ & Paper report \\
\hline \hline ArticleFirstPage & $:$ & 1 \\
\hline \hline ArticleLastPage & $:$ & 4 \\
\hline \hline & & RegistrationDate : 2000-2-1 \\
ArticleHistory & $:$ & Received \\
& $:$ 2000-2-1 \\
\hline \hline ArticleCopyright & $:$ & BioMed Central Ltd2000 \\
\hline \hline ArticleGrants & $:$ & \\
\hline \hline ArticleContext & $:$ & 130591111 \\
\hline \hline
\end{tabular}




\section{Paul Denny}

\section{Abstract}

Mouse chromosomes carrying deletions have been produced using a combination of targeted and random integration of selectable markers followed by specific excision by a recombinase.

\section{Significance and context}

Chromosomes carrying deletions are useful biological tools. They can be used to study the requirement for two functional copies of a gene (or a gene complex) and to map recessive mutations to a genomic region. Methods of inducing deletions usually fall into two classes: those that produce random deletions, and those that produce precisely targeted deletions, for example by homologous recombination. Su et al. describe a method for combining targeted and random insertion of vector sequences into the genome in mouse embryonic stem (ES) cells in such a way that the sequences can subsequently be excised to produce deletions that share a common breakpoint but differ in size.

\section{Key results}

$\mathrm{Su}$ and colleagues generated a set of deletions anchored around the X-linked Hprt gene. Deletions were of varying sizes, with the largest estimated to be 1 centiMorgan in size by comparison with the genetic map. About $20 \%$ of the ES cell lines tested carried a deletion. A further deletion cluster was produced on mouse chromosome 11 and was used to construct a map of the targeted region, which was then compared with a physical map based on bacterial artificial chromosomes (BACs). Deletions of up to $8 \mathrm{Mb}$ were identified in this second region.

\section{Methodological innovations}

The method described by Su et al. for producing mouse chromosomes carrying deletions has three stages. The initial steps introduce two different vectors into the genome of ES cells deficient for Hprt, which enables cells to grow in a medium containing hypoxanthine, aminopterin and thymidine (HAT). The first vector is a targeting vector carrying the 5 ' half of the Hprt gene, a suitable genomic fragment, a 
loxP site and a neomycin-resistance gene, and is introduced by homologous recombination. The second vector carries the $3^{\prime}$ half of the Hprt gene, a loxP site and a puromycin-resistance gene, and this is introduced into the ES cells by retroviral infection, in a relatively random fashion. Recombination between these two inserted sequences, mediated by a specific recombinase (Cre), excises sequences between the loxP sites. Where the relative orientation of inserted random and specific vectors is appropriate, this leaves a functional Hprt gene and removes the drug-resistance genes. This means that cells carrying potential deleted chromosomes can be selected on the basis of sensitivity to puromycin and neomycin and ability to grow in HAT.

\title{
Links
}

One of the genome regions used to demonstrate the effectiveness of the method is on mouse chromosome 11 and is being physically mapped by some of the same authors. Information can be found on the Mouse genome project pages.

\section{Reporter's comments}

A novel combination of existing techniques is used to produce nested sets of deletions. The method requires knowledge of sequence in only one genomic region and simplifies the identification of precise deletion breakpoints, which is currently problematic. One limitation of the method is that it requires a high level of expertise in the culture and manipulation of ES cells and retrovirus-derived vectors. This expertise is, however, becoming more widespread and it should be possible for the method to be used in many laboratories.

\section{Table of links}

\author{
Nature Genetics
}

Mouse genome project 


\section{References}

1. Su H, Wang X, Bradley A: Nested chromosomal deletions induced with retroviral vectors in mice. Nat Genet. 2000, 24: 92-95. 1061-4036

This PDF file was created after publication. 